\title{
PROGRESS REPORT \\ DE-FG02-89ER60857 \\ Human Chromosome 21: Linkage Mapping and Cloning \\ in Yeast Artificial chromosomes
}

Stylianos E. Antonarakis, PI

\section{Mapping of YACS}

our initial attempts to create YACs had generated a total of 76 human genome containing YACs. (Fifty-six from partial EcoRI digest of somatic cell hybrid WAV-17 which is a human chromosome 21-only hybrid, and 20 from flowsorted chromosome 21). The mapping of these YACs was carried out using the following methods:

1.1 Cloning of endi of YACs and map them by hybridization to a somatic cell hybrid panel that divides chromosome 21 into several subfragments. Ends have been generated in about half of the YACs and 13 have been mapped by hybridization.

1.2 Nucleotide sequencing of the ends of the YACs and map by PCR amplification in somatic cell hybrids. The nucleotide sequencing can be performed on the cloned ends or after anchor PCR of the ends. All of the ends that have been cloned to date have been sequenced and oligonucleotides have been designed to produce and map the STS of the ends of YACS.

1.3 STS marking and mapping of YACs. The YACs generated have been arranged in 96 microtiter well plates and their DNAs have been used as templates for amplification using sinromosome 21 STS. The STS used to date are: D21S120, D21S171, D21S156, HMG14, IFNAR, 21-GI12, 21-GT14, 21-GT05, 21-GT1.7. All. STS have been generated in our laboratories except for D21S120. All SIS are well mapped in the physical or the linkage map of human chromosome 21 . The positive YACs can be used as seed clones for the built-up of the initial contigs. Our initial first contig consists of three YACs for a total length of about $1 \mathrm{MB}$ and contains EIS2 and D21S156.

\section{Development of STS}

A number of chromosome 21 specific STS have been developed in our laboratories as part of the physical mapping project. Most of our STS are also highly polymorphic because they contain a dinucleotide or tri- or tetranucleotide repeat or a poly A tract of an Alu sequence. In addition, mast of our STS have been placed in the linkage map after genotyping in the CEPH families. The SIS have been generated as follows:

2.1 Screening of a chromosome 21-specific plasmid library from Lawrence Livermore National Laboratories. The screening has been performed using (GT) 10 and other repeats $\left[(\mathrm{AT})_{10},\left(\mathrm{~A}_{2} \mathrm{~T}\right)_{10}:(\mathrm{GA})_{10} \mathrm{j}\right.$. 
2.2 Sequencing of the ends of YACs after cloning or after anchor PCR.

2.3 Sequencing of Alu-PCR products from somatic cell. hybrid WAV-17.

2.4 Sequencing of lambda, plasmid or cosmid clones that contain a INA fragment known to map on human chromosame 21.

The plans for the next funding year are:

1. To generate more YACs from WAV-17 somatic cell hybrid line and flowsorted chromosomes.

2. Map the YACs on chromosome 21 and develop contigs.

3. Generate STS that will contribute to the contig development and bridge the linkage and the physical map.

4. Generate STS that are parts of CDNAs.

\section{DISCLAIMER}

This report was prepared as an account of work sponsored by an agency of the United States Government. Neither the United States Government nor any agency thureof, nor any of their employees, makes any warranty, express or implied, or assumes any legal liability or responsi. bility for the accuracy, completeness, or usefuliess of any information, apparatus, product, or process disclosed, of represents that its use would not infringe privately owned rights. Reference hereis to any specific co.nmercial product, prosess, or service by trade name, trademark, manufacturer, or otherwise does not necessarily constitute or imply its endorsement, recommendation, of favoring by the United States Governmeit or any agency thereof. The views and opinions of authors expressed herein do not necessarily state or reflect those of the United States Government or any agency thereof. 

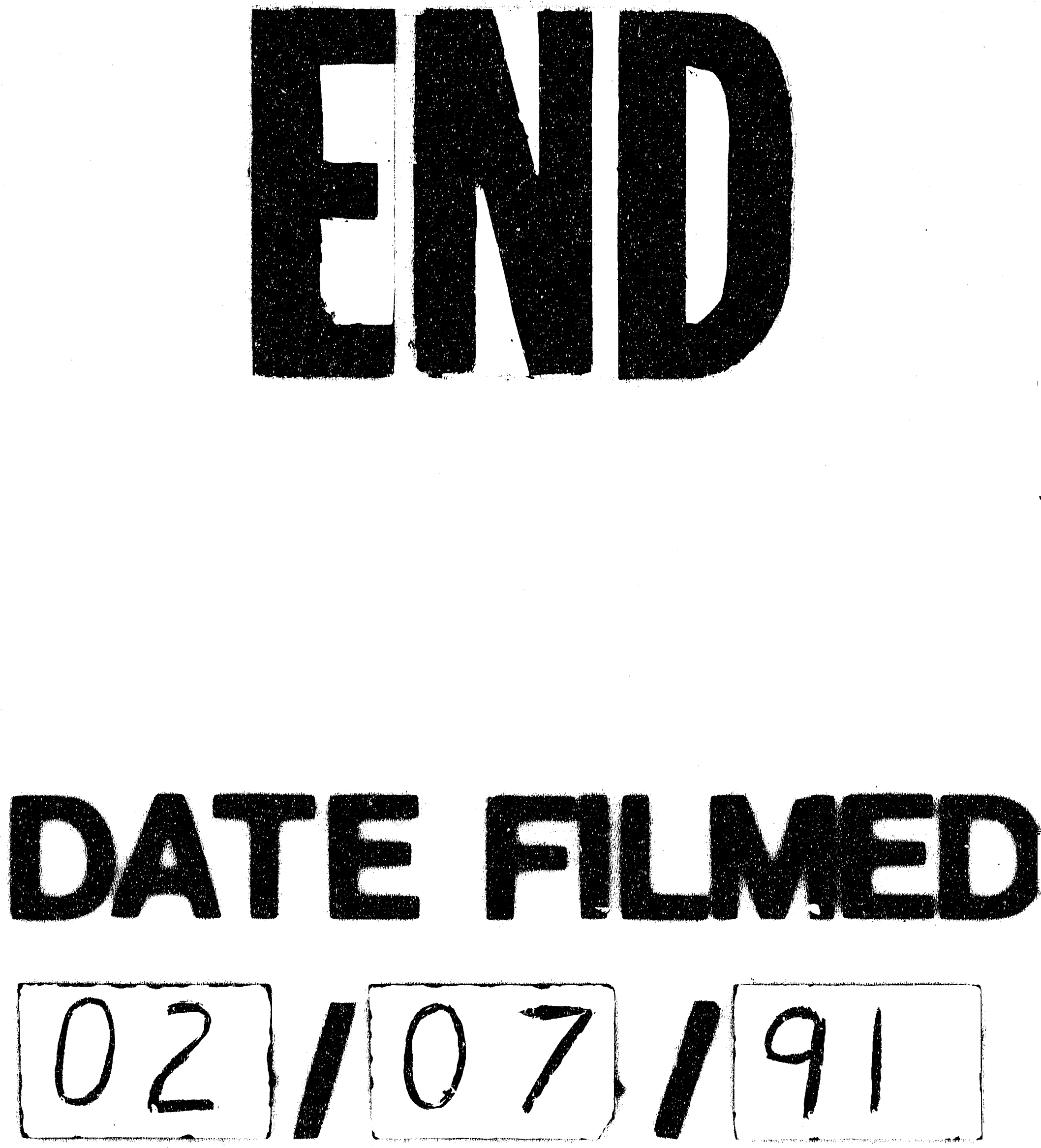
